\title{
The economic impact of AIDS in Africa
}

\author{
Alan W Whiteside MA(East Anglia)
}

\begin{abstract}
AW Whiteside. The economic impact of AIDS in Africa. Can J Gastroenterol 2000;14(8):685-690. The experience of acquired immune deficiency syndrome (AIDS) in Africa is very different from that in the developed world. In the West, AIDS affects few people, and for those who are infected, it is an increasingly manageable illness. In Africa, huge numbers of people are being infected - mainly young adults through sexual intercourse. This is having a dramatic effect on key demographic indicators. Child mortality in some countries has doubled, while up to 25 years of life expectancy have been lost. The economic impact of AIDS is difficult to establish, but it is certainly leading to increased poverty in African families and communities. Development advances are being reversed, but the impact is incremental rather than catastrophic.
\end{abstract}

Key Words: Acquired immune deficiency syndrome; Africa; Demography; Development; Economics; Human immunodeficiency virus

\section{Impact économique du sida en Afrique}

RÉSUMÉ : L'expérience du syndrome d'immunodéficience acquise (SIDA) en Afrique est très différente de celle des pays industrialisés. En Occident, le sida affecte peu de gens et pour les malades, la maladie est de plus en plus traitable. En Afrique, d'importants contingents de personnes deviennent infectées chaque jour, principalement de jeunes adultes lors des rapports sexuels. Ce phénomène exerce un effet dramatique sur les principaux indicateurs démographiques. La mortalité infantile dans certains pays a doublé alors que l'espérance de vie a décliné, parfois de 25 ans. L'impact économique du sida est difficile à évaluer, mais cette maladie donne certainement lieu à un accroissement de la pauvreté dans les familles et les communautés africaines. Les progrès du développement sont renversés, mais l'impact est graduel plutôt que d'être catastrophique.
A cquired immune deficiency syndrome (AIDS) is the first, and so far the only, disease to have a United $\mathrm{Na}$ tions Agency (Joint United Nations Programme on HIV/AIDS [UNAIDS]) established especially to deal with it and its consequences. To people living in the developed world, this might seem puzzling. In these countries, the massive human immunodeficiency virus (HIV) epidemic feared in the mid-1980s has not materialized, and the prevalence of HIV infection is low. HIV is still spreading among clearly defined, usually disadvantaged, groups (1). For those unfortunate enough to be infected, AIDS is no longer the automatic death sentence it once was. The introduction of highly active antiretroviral therapy (HAART) means that mortality rates among people with HIV infection have begun to decline in the developed world. Increasingly, HIV-related illness is seen as a chronic but manageable illness, albeit at a price. It is estimated that antiretroviral therapy costs between US $\$ 8,000$ and US $\$ 12,000 /$ patient/annum (2).
The situation in Africa is very different. Sub-Saharan Africa has the worst epidemic in the world. In 1998, it was estimated that over two-thirds of those living with HIV were in Africa, and $83 \%$ of global AIDS deaths have occurred there (3). The HIV and AIDS epidemics in Africa are very different from those in the rest of the world. Distinguishing characteristics are as follows.

- Modes of transmission. In Africa, the vast majority of infections are heterosexually transmitted - as many as $80 \%$ - and the balance are mainly mother to child infections.

- Location of the epidemic. Figure 1 shows a typical age and sex profile of the epidemic. In general, more women than men are infected, and women are infected at a younger age than their male counterparts.

- Scale of the problem. The main sources of data are the antenatal clinic (ANC) attendee surveys. While these

This mini-review was prepared from a presentation made at the World Congress of Gastroenterology, Vienna, September 6 to 11, 1998

Health Economics and HIV/AIDS Research Division, University of Natal, South Africa

Correspondence and reprints: Dr Alan Whiteside, University of Natal, Durban 4041, South Africa. Telephone +27-31-2602592,

fax+27-31-2602587, e-mail freeman@shep.und.ac.za

Received for publication June 22, 1999. Accepted June 28, 1999 


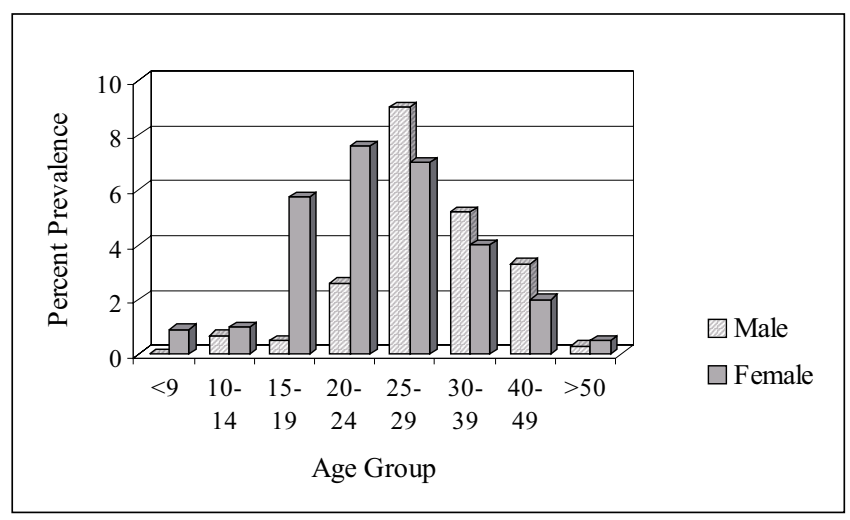

Figure 1) Age and sex differences in human immunodeficiency virus infection in rural KwaZulu-Natal (1992)

surveys have their limitations (4), they provide the best and often the only source of information. In Western Europe, the highest recorded HIV prevalence $(0.42 \%)$ was found in women attending ANCs in urban areas (France, 1994). By contrast, in Eastern and Southern Africa, the lowest urban ANC prevalence recorded in the 1990s was $1.2 \%$ in Angola, and the highest was $38.5 \%$ in Botswana (5). The ANC HIV prevalence rates for Swaziland and South Africa are shown in Figure $2(6,7)$; these rates are typical for the region.

- Prognosis. Although the time from infection to illness and death is estimated to be 10 years and, with the introduction of HAART, increasing in developed countries, it is much shorter in Africa. Estimates of time from infection to AIDS range from two to 7.5 years, but these estimates are for seroprevalent rather than seroincident cohorts (8). A group of demographers used a period of 6.5 years from infection to death in modelling the epidemic for Southern Africa (9).

\section{IMPACT OF AIDS}

Clearly, a disease that is so widespread, and that has such effects on morbidity and mortality, will have serious implications for Africa. The situation is made even more bleak by the lack of resources, both for prevention and for dealing with its impact, across most of the continent. A discussion of the economic impact is, however, only part of the picture. The extent of the economic impact depends on the demographic impact. Furthermore, the economic impact, as measured by economists, may not be that apparent, and other indicators may be more important, in particular the effect on development.

Demographic effects of AIDS: Because the presence of AIDS means that significant numbers of adults and children will die, it affects the major demographic processes of mortality and fertility. Because HIV is spread mainly through sexual transmission, most of those infected are between 20 and 40 years of age, and die five to 10 years later.

AIDS has been identified as the major cause of death in adults aged 15 to 44 years in Abidjan and in adults aged 15 to

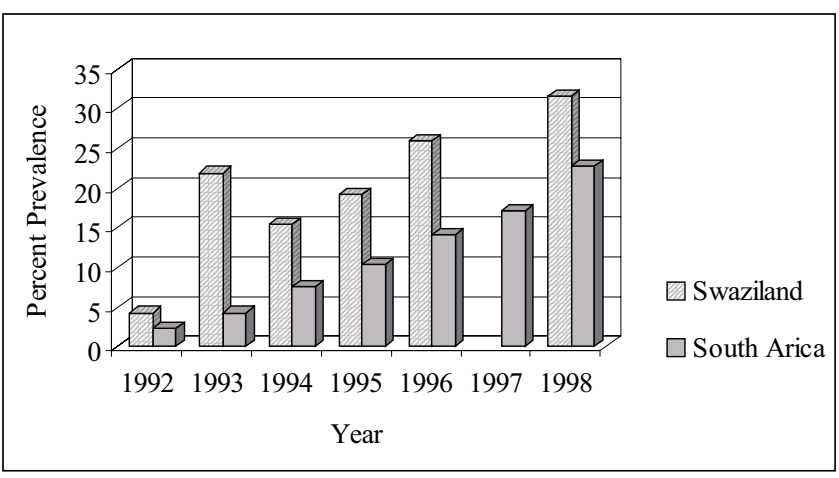

Figure 2) National prevalence of human immunodeficiency virus in Swaziland and South Africa. (No data were available for Swaziland in 1997). Data from reference 6 and 7

59 years in Tanzania $(10,11)$. In a rural Ugandan cohort, with an HIV prevalence of about $14 \%$ in adults, AIDS accounted for approximately $40 \%$ of deaths of all adults (12). AIDS is now the most common cause of death in Africa, and, given the age of those dying, it is also a major cause of orphaning. The World Health Organization estimated that, in Africa, as many as 10 million children have been orphaned since the beginning of the epidemic (13). A study in rural Tanzania found that $9 \%$ of children were orphans and that $14 \%$ of households had at least one orphan (14). In Masaka, a rural part of Uganda, approximately $10 \%$ of children were orphans (15).

Women who are infected may pass on the infection to the fetus before birth, to the child during delivery or through breastfeeding. In Africa, it is believed that about 30\% of children will be infected (although there are various interventions that can reduce the risk). Because most infected children die before their fifth birthdays, child and infant mortality will increase. A child born to an HIV-infected mother may only have a $30 \%$ chance of being infected, but has a close to $100 \%$ chance of being orphaned. The increased rates of orphaning may, in turn, increase child mortality rates. Orphans in Africa may be cared for by the extended family, the community or siblings. State or nongovernmental agency support is very rare. As the number of orphans rises, these systems are coming under increasing pressure, and it is likely that orphan mortality will rise. Table 1 shows the modelled impact of AIDS on child mortality rates in some of the worst affected countries in Africa (16).

A further major demographic impact of AIDS is on life expectancy; deaths of children and young adults have a very adverse effect on life expectancy (Table 2) (16). According to the models developed by the United States Bureau of the Census, some countries in Southern Africa had already lost over 20 years of life expectancy in 1998, and the situation is certain to get much worse.

Economic impact: The economic effect of AIDS will not be uniform across countries or even within societies. The impact will be felt at various levels and to varying degrees. Effects on the economy result because individuals who become ill and die are all part of the economy, ie, producers or con- 
TABLE 1

Mortality rates per $\mathbf{1 0 0 0}$ for children with and children without acquired immune deficiency syndrome (AIDS) in selected countries

\begin{tabular}{lcccc}
\hline & \multicolumn{2}{c}{1998} & \multicolumn{2}{c}{2010} \\
Country & $\begin{array}{l}\text { Without } \\
\text { AIDS }\end{array}$ & $\begin{array}{c}\text { With } \\
\text { AIDS }\end{array}$ & $\begin{array}{c}\text { Without } \\
\text { AIDS }\end{array}$ & $\begin{array}{c}\text { With } \\
\text { AIDS }\end{array}$ \\
\hline Malawi & 190.3 & 231.6 & 136.0 & 202.6 \\
Zambia & 125.7 & 181.2 & 96.9 & 160.7 \\
Namibia & 62.1 & 125.5 & 37.5 & 118.8 \\
Botswana & 57.4 & 121.1 & 38.3 & 119.5 \\
Swaziland & 83.8 & 103.4 & 77.5 & 152.2 \\
Kenya & 64.9 & 107.0 & 45.4 & 105.2 \\
South Africa & 69.7 & 95.5 & 48.5 & 99.5 \\
Zimbabwe & 50.5 & 125.4 & 31.8 & 115.6 \\
\hline
\end{tabular}

Data from reference 16

sumers. The effect of an infection is felt first and most immediately by the person who is ill, and by his or her family. It then ripples through the household, community and eventually the country.

What, then, is known of the economic effects? There is actually surprisingly little evidence.

Households: At the household level, AIDS may be disastrous. The infected individual requires medical care and possibly special foods, thus increasing demands on household resources. At the same time, if the person is an adult, the illness and death reduce the household production capacity, resulting in a decline in household income. Thus, households are caught in a double bind of needing more resources when these may be reduced.

There is only one recent, detailed study of the impact of AIDS on households in Anglophone Africa - from the Kagera region of Tanzania. The first results of this study have been reported at various conferences but are not yet available in a comprehensive, published form. Households experiencing an adult death respond by voluntarily adjusting household size and by reducing their supply of labour to farming, wage employment and nonfarm self employment in the first three months after the death. In addition, there is a decline in per capita growth rates of both income and consumption; medical treatment and funeral costs pose a major financial burden, and female children may be taken out of school (17).

Across the Ugandan border, in the Rakai district, adult mortality was found to lead to a decline in household economic status, as measured through the possession of durable goods such as bicycles or vehicles (18). The death of an HIV positive adult is more likely to lead to the sale of such goods than the death of an HIV-negative adult, indicating that HIV-affected households have far fewer resources, either before or after the infection.

A source of concern is that there is no published information on the effects of AIDS in urban and periurban areas of Africa. Growing numbers of people live in these areas (in
TABLE 2

Life expectancy for people with and people without acquired immune deficiency syndrome (AIDS) in selected countries

\begin{tabular}{lcccccc}
\hline Country & $\begin{array}{c}\text { Without } \\
\text { AIDS }\end{array}$ & $\begin{array}{c}\text { With } \\
\text { AIDS }\end{array}$ & $\begin{array}{c}\text { Years } \\
\text { lost }\end{array}$ & $\begin{array}{c}\text { Without } \\
\text { AIDS }\end{array}$ & $\begin{array}{c}\text { With } \\
\text { AIDS }\end{array}$ & $\begin{array}{c}\text { Years } \\
\text { lost }\end{array}$ \\
\hline Malawi & 51.1 & 36.6 & 14.5 & 56.8 & 34.8 & 22.0 \\
Zambia & 56.2 & 37.1 & 19.1 & 60.1 & 37.8 & 22.3 \\
Swaziland & 58.1 & 38.5 & 19.6 & 63.2 & 37.1 & 26.1 \\
Zimbabwe & 64.9 & 39.2 & 25.7 & 69.5 & 38.8 & 30.7 \\
Botswana & 61.5 & 40.1 & 21.4 & 66.3 & 37.8 & 28.5 \\
Namibia & 65.3 & 41.5 & 23.8 & 70.1 & 38.9 & 31.2 \\
Kenya & 65.6 & 47.6 & 18.0 & 69.2 & 43.7 & 25.5 \\
South Africa & 65.4 & 55.7 & 9.7 & 68.2 & 48.0 & 20.2 \\
\hline
\end{tabular}

Data from reference 16

1995 , it was estimated that $37 \%$ of Africans lived in urban areas and that this percentage would rise to $41 \%$ by 2000 ). Firms and enterprises: The next level at which an economic impact might be expected is on firms or production units. AIDS will affect workplaces because of its effects on productivity, costs and the national economic environment.

Key questions regarding the impact of AIDS on productivity relate to who are affected, in terms of skills and productivity in the private sector, and the nature of the labour market in the country and the sector. If, for example, there is a large pool of unemployed or underemployed people and the cost of replacing labourers is low, then AIDS may have little impact. If, on the other hand, the labourers are skilled or difficult to replace, then its impact may increase.

Productivity will be affected if employees fall ill but remain on the payroll, and when skilled or experienced staff fall ill or die. Research in Zambia has shown that the mortality rate among formal sector employees rose from $0.24 \%$ in 1987 to $2.1 \%$ in 1993 (19). This means that a company with 1000 employees might expect about 21 employees to die each year, and 19 of the deaths may be attributed to AIDS.

In Kenya, a survey of five companies found that AIDS was costing US $\$ 45 /$ employee/annum (3\% of company profits), and it could rise as high as US $\$ 120 /$ employee/annum (8\% of profits) by 2005 (20). A comparison of research in the private sector in Kenya, Zambia and Malawi shows that absenteeism accounts for between $25 \%$ to $54 \%$ of costs, as well as lower productivity and loss of experienced staff (21). By contrast, a study of the Makandi Tea and Coffee Estate Limited in Malawi (22) found that

...the effects of HIVIAIDS on current levels of expenditure at Makandi are negligible. The major components of HIV/AIDS-related expenditure are the estimated attributable cost of employee medical service provision and the unexpected pension scheme commitments resulting from the higher death in service rate. 
TABLE 3

Impact of acquired immune deficiency syndrome on employee benefits: Costs as a percentage of salary

\begin{tabular}{lccc}
\hline Benefit & $\mathbf{1 9 9 5}$ & $\mathbf{2 0 0 0}$ & $\mathbf{2 0 0 5}$ \\
\hline Lump sum at death & 1.5 & 3.7 & 6.0 \\
Spouse's pension & 4.0 & 7.5 & 10.0 \\
Disability pension & 1.5 & 2.3 & 3.0 \\
Total & 7.0 & 13.5 & 19.0 \\
\hline
\end{tabular}

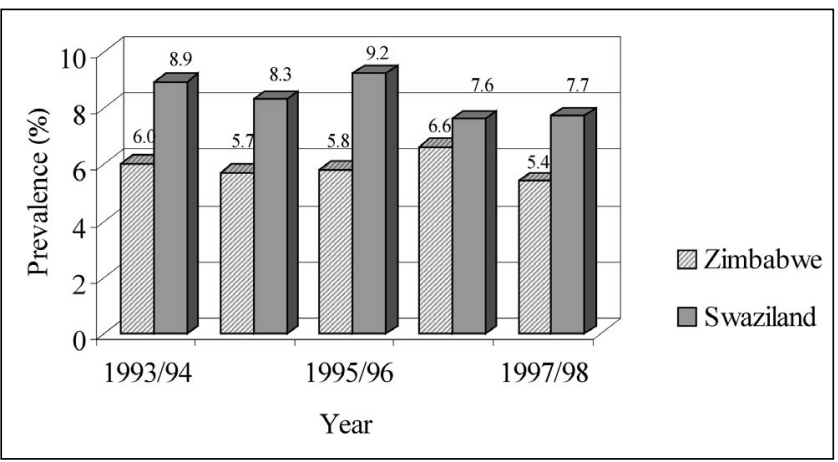

Figure 3) Expenditure on health as a percentage of central government recurrent revenue. Data from references 28,29

The cost of AIDS to employers depends on the conditions of employment, the number of staff and the benefits that are provided. It is possible that more advanced African economies will be more adversely affected. For example, in South Africa, benefits include group life insurance, pensions and medical aid. A rather sobering calculation performed by Metropolitan Life is shown in Table 3 (P Doyle, personal communication). If payroll costs do not rise, benefits are reduced.

The effect of AIDS on the economic environment is harder to assess. The private sector may be able to adapt to increased morbidity and mortality in the workforce. The government and many of the service-providing parastatals do not have this ability; employees who become ill may be retained on the payroll for months, during which time their jobs may not be done. Thus, the business environment may suffer. Two other concerns for the private sector are the impacts on markets, especially luxury purchases and investment. It is difficult to assess the market impact of AIDS. Investment effects may be clearer. In the more developed African countries, life insurance and pension funds are important sources of capital for both the private sector and the government. The existence of AIDS means that both these instruments of investment will suffer, and insurance companies will seek to avoid insuring both HIV-positive people and those who they fear may become HIV-positive. Pension funds will see members withdrawing before reaching pensionable age and consuming their accumulated benefits. Macroeconomic impact: Will the epidemic have an impact at the macroeconomic level? There is no hard evidence. Attempts to model the macroeconomic impact have been fraught with difficulty. The mechanisms through which the epidemic may affect macroeconomies, as a result of the illness and death of productive members, and the diversion of resources from savings (and eventually investment) to care, have been identified (23). There have also been attempts to model the economic impact for specific countries, including Tanzania (24), Cameroon (25) and Zambia (26). These models show that HIV may reduce the rate of economic growth, and, over a period of 20 years, this reduction may be significant (up to $25 \%$ lower than it would otherwise have been). However, to make this prediction, projections of both the AIDS epidemic and the economic trends have to be combined. Both are difficult to model, and combining them compounds the uncertainty. The dire macroeconomic predictions are undermined by the economic growth rates in Uganda (2.7\% between 1985 and 1995) and Botswana (6.1\%) (27); Uganda has perhaps the most advanced AIDS epidemic, while Botswana has the fastest growing one.

Health care costs: What is the effect of AIDS on health care costs? The answer depends on who bears these costs. In most African societies, the bulk of formal Western health care facilities are provided by the state. In theory, the increase in HIV and AIDS cases should lead to the government planning of treatment regimens that would provide the most cost effective care for patients, taking into account other demands for care. Figure 3 shows that government expenditures on health care have not increased as a proportion of the budget $(28,29)$; there are three possible reasons, given the lack of increase in revenue:

- The health sector is coping with its current resources and is reallocating them to provide for the increased demand for care.

- Patients with HIV-related illness are not receiving care from the state sector, but the burden and costs are being borne by the individuals and households.

- The health sector is trying to cope but lacks a system of allocation of resources so that more is being done with the same quantity and, consequently, all care is suffering.

Unfortunately, the preliminary evidence suggests that the second and third scenarios are occurring in much of Africa. Under these scenario, AIDS does not have a direct and measurable economic impact, but the households and communities face increased impoverishment. Furthermore, the health status of the nation will suffer in the long run.

\section{DEVELOPMENT IMPLICATIONS}

Obtaining a clear picture of the economic implications of AIDS is somewhat confounded by the very complex nature of economic interactions; coping mechanisms come into play at all levels, and many transactions may not be measured. Traditionally, the gross domestic product (GDP) of a country is deemed to be that which enters the marketplace or to which a value can be assigned (for example, subsistence crops). This means that many of the things that make up the 


\section{TABLE 4}

Life expectancy and position in the human development index of eight African countries

\begin{tabular}{|c|c|c|c|c|c|c|c|c|c|c|}
\hline & \multicolumn{2}{|c|}{1996} & \multicolumn{2}{|c|}{1997} & \multicolumn{2}{|c|}{1998} & \multicolumn{2}{|c|}{1999} & \multicolumn{2}{|c|}{2000} \\
\hline & $\begin{array}{c}\text { Life } \\
\text { expectancy }\end{array}$ & Rank & $\begin{array}{c}\text { Life } \\
\text { expectancy }\end{array}$ & Rank & $\begin{array}{c}\text { Life } \\
\text { expectancy }\end{array}$ & Rank & $\begin{array}{c}\text { Life } \\
\text { expectancy }\end{array}$ & Rank & $\begin{array}{c}\text { Life } \\
\text { expectancy }\end{array}$ & Rank \\
\hline South Africa & 63.2 & 100 & 63.7 & 90 & 64.1 & 89 & 54.7 & 101 & 53.2 & 103 \\
\hline Swaziland & 57.8 & 110 & 58.3 & 114 & 58.8 & 115 & 60.2 & 113 & 60.7 & 112 \\
\hline Kenya & 55.5 & 128 & 53.6 & 134 & 53.8 & 137 & 52.0 & 136 & 51.3 & 138 \\
\hline Zambia & 48.5 & 136 & 42.6 & 143 & 42.7 & 146 & 40.1 & 151 & 40.5 & 153 \\
\hline Malawi & 45.5 & 157 & 41.1 & 161 & 41 & 161 & 39.3 & 159 & 39.5 & 163 \\
\hline
\end{tabular}

Data from references 30-34

fabric of society are not measured; child care, for example, is never measured as an economic output.

The inadequacy of economic measures such as the GDP was recognized by the United Nations Development Programme in 1990, and an alternative measure was introduced - the human development index. The human development index was designed to capture as many aspects of human development as possible in one simple composite index and includes three fundamental dimensions - a long and healthy life, knowledge and a decent standard of living. Longevity is measured by life expectancy at birth; education attainment by adult literacy (two-thirds weight) and combined primary, secondary and tertiary enrolment ratios (one-third weight); and standard of living by the real GDP.

The first Human Development Report to consider the impact of AIDS on life expectancy was published in 1998. Subsequent reports considered HIV in demographic predictions but not for all countries. Thus, as shown in Table 4, the effects of mortality on life expectancy in Zambia and Malawi have bottomed out. Life expectancy appears to have reached the lowest levels and started to recover slowly. It should be

\section{REFERENCES}

1. Schechter MT, Strathdee SA, Cornelisse PGA, et al. Do needle exchange programmes increase the spread of HIV among injection drug users?: an investigation of the Vancouver outbreak. AIDS 1999;13:F45-51.

2. The World Bank. Confronting AIDS: Public Priorities in a Global Epidemic. A World Bank Policy Research Report. New York: Oxford University Press, 1997.

3. Report on the Global HIV/AIDS Epidemic. Geneva: UNAIDS/WHO, 1998.

4. UNAIDS Best Practice Collection. Reading Regional Consensus on Improved Behavioural and Sero-surveillance for HIV. Report from a Regional Conference in East Africa. Geneva: UNAIDS, 1998.

5. Report on the global HIV/AIDS epidemic. Geneva: UNAIDS/WHO, 1998:70-1.

6. HIV in Botswana and Swaziland. AIDS Anal Afr 1999;10(2):12.

7. Whiteside A, Sunter C. AIDS: The Challenge for South Africa. Cape Town: Human and Rousseau, 2000.

8. Grant AD, Ojomond G, De Cock KM. Natural territory and spectrum of disease in adults with HIV/AIDS in Africa. AIDS 1997;11(Suppl B):S43-54. noted that the demographers have not modelled the impact of AIDS for Swaziland, which is why, despite the high levels of infection, no decrease in life expectancy is recorded. (29. 31).

The impact of AIDS goes far beyond the economic. AIDS is resulting in growing impoverishment, and stress in households and communities across the continent. At the national level, it is having a damaging effect on development indicators.

\section{CONCLUSIONS}

It is clear that the AIDS epidemic in Africa is an enormous challenge to the governments of the region. AIDS will have an impact on their demographic makeup and trends, and will reverse improvements in many of the development indicators. The economic impacts will be complex and take a long time to develop. The impact on the people of Africa will certainly be very serious and will lead to increased poverty and misery. The impacts may seem very far away to people living in the developed world, and will be less obvious because the impact is incremental rather than catastrophic.

9. Gregson S, Zaba B, Garnett GP, Anderson RM. Projections of the magnitude of the HIV/AIDS epidemic in Southern Africa. In: Whiteside A, ed. Implications of AIDS for Demography and Policy in Southern Africa. Pietermaritzburg: University of Natal Press, 1998:27-60.

10. Adetunji JA. Assessing the mortality impact of HIV/AIDS relative to other causes of adult deaths in sub-Saharan Africa. Conference on the Socio-Demographic Impact of AIDS in Africa. Durban, February 3-6, 1997.

11. Boerma JT, Ngalula J, Isingo R, et al. Levels and causes of adult mortality in rural Tanzania with special reference to HIV/AIDS. Conference on the Socio-Demographic Impact of AIDS in Africa. Durban, February 3-6, 1997.

12. Nunn AJ, Mulder DW, Kamali A, et al. Five-year HIV-1 associated mortality in a rural Ugandan population. Conference on the SocioDemographic Impact of AIDS in Africa. Durban, February 3-6, 1997.

13. World Health Organization. The current global situation of the HIV/AIDS epidemic. Global Programme on AIDS. Memo 3. Geneva: World Health Organization, 1996.

14. Urassa M, Ngweshemi JZL, Isingo R, Kumogola Y, Boerma JY. Orphanhood, child fostering and the AIDS epidemic in rural 
Tanzania. Conference on the Socio-Demographic Impact of AIDS in Africa. Durban, February 3-6, 1997.

15. Kamali A, Whitworth JAG, Ruberantwari A, Carpenter LM. Impact of the HIV-1 epidemic in orphan mortality in a rural Uganda population cohort. Conference on the Socio-Demographic Impact of AIDS in Africa. Durban, February 3-6, 1997.

16. US Bureau of the Census, Report WP/98, World Population Profile: 1998. Washington: US Government Printing Office, 1999.

17. Whiteside A, Stover J. The demographic and economic impact of AIDS in Africa. AIDS 1997;11(Suppl B):S55-61.

18. Menon R, Wawer MJ, Konde-Lule JK, Seqankambo NK, Li C. The economic impact of adult mortality on households in the Rakai district, Uganda. In: Ainsworth M, Fransen L, Over M, eds. Confronting AIDS: Evidence from the Developing World. Brussels: European Commission, 1997:325-38.

19. Baggeley R, Chilangwa D, Godfrey-Faussett P, Porter J. Impact of AIDS on Zambian business. VIII International Conference on AIDS and STDs in Africa. Marrakech, December 6-13, 1993. (Abst WRT 0031).

20. Forsyth S, Rau B, eds. AIDS in Kenya: Socio-Economic Impact and Policy Implications. Arlington: Family Health International/AIDSCAP, 1996.

21. Lowenson R, Whiteside A. Social and Economic Issues of HIV/AIDS in Southern Africa. Harare: SAfAIDS, 1997.

22. Jones C. The Microeconomic implications of HIV/AIDS (Dissertation). East Anglia: University of East Anglia, 1996:42.

23. Over M. The Macroeconomic Impact of AIDS in Sub-Saharan Africa.
African Technical Department, Population, Health and Nutrition Division, Technical Working Paper No 3. Washington: World Bank, 1992.

24. Cuddington IT. Modelling the macroeconomic effects of AIDS, with an application to Tanzania. World Bank Econ Rev 1992;7:403-17.

25. Kambou G, Devarajan S, Over M. The economic impact of AIDS in an African country: simulations with a computable general equilibrium model of Cameroon. J Afr Econ 1992;1:109-30.

26. Forgy L, Mwanza A. The Economic Impact of AIDS in Zambia. Lusaka: Ministry of Health, 1994.

27. The World Bank. World Development Report 1997. New York: Oxford University Press, 1997.

28. Annual Report Financial Year 1997/98, Mbabane: Central Bank of Swaziland, 1998:44.

29. Zimbabwe Country Profile, 1998-1999. London: The Economist Intelligence Unit, 1998.

30. United National Development Programme. Human Development Report 1996. New York: Oxford University Press, 1996.

31. United National Development Programme. Human Development Report 1997. New York: Oxford University Press, 1997.

32. United National Development Programme. Human Development Report 1998. New York: Oxford University Press, 1998.

33. United National Development Programme. Human Development Report 1999. New York: Oxford University Press, 1999.

34. United National Development Programme. Human Development Report 2000. New York: Oxford University Press, 2000. 


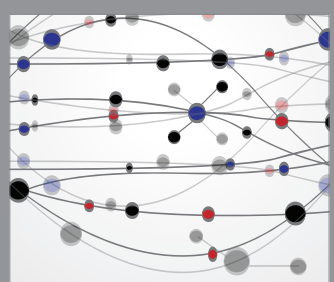

The Scientific World Journal
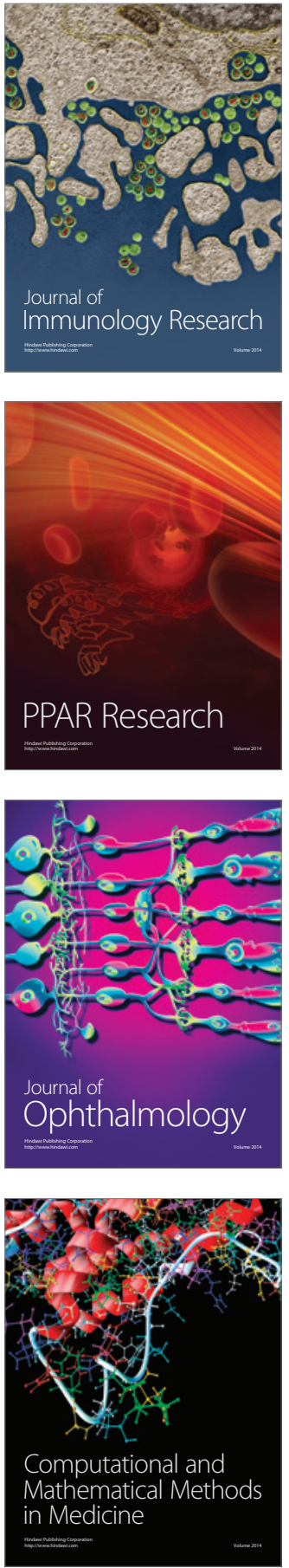

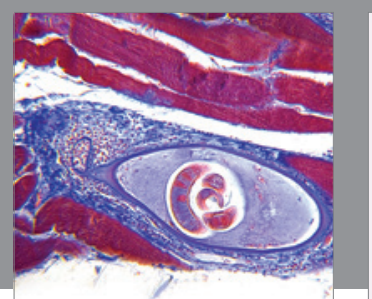

Gastroenterology Research and Practice

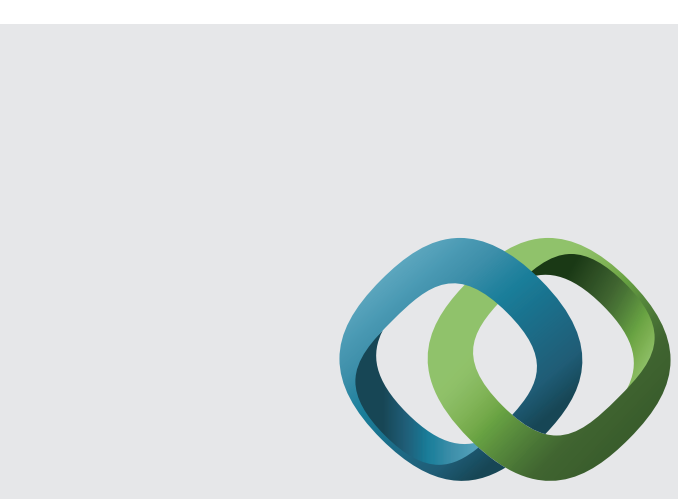

\section{Hindawi}

Submit your manuscripts at

http://www.hindawi.com
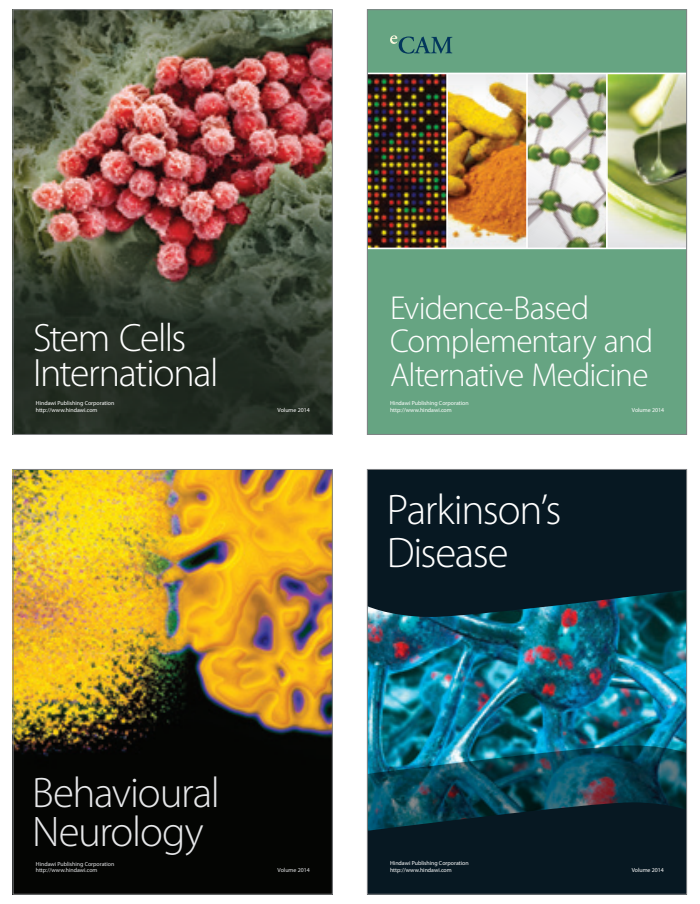
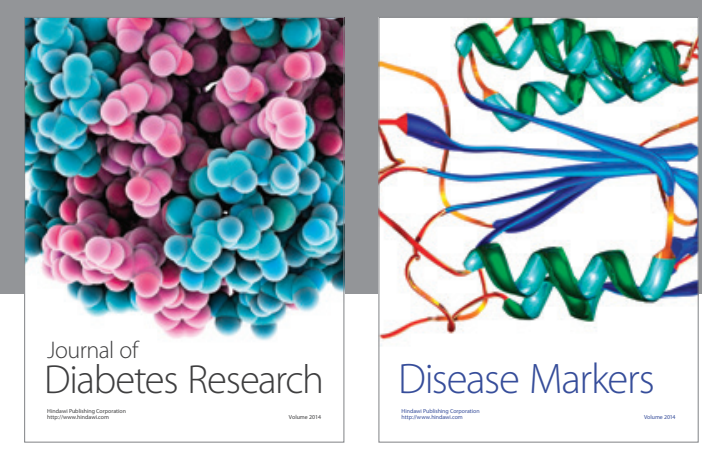

Disease Markers
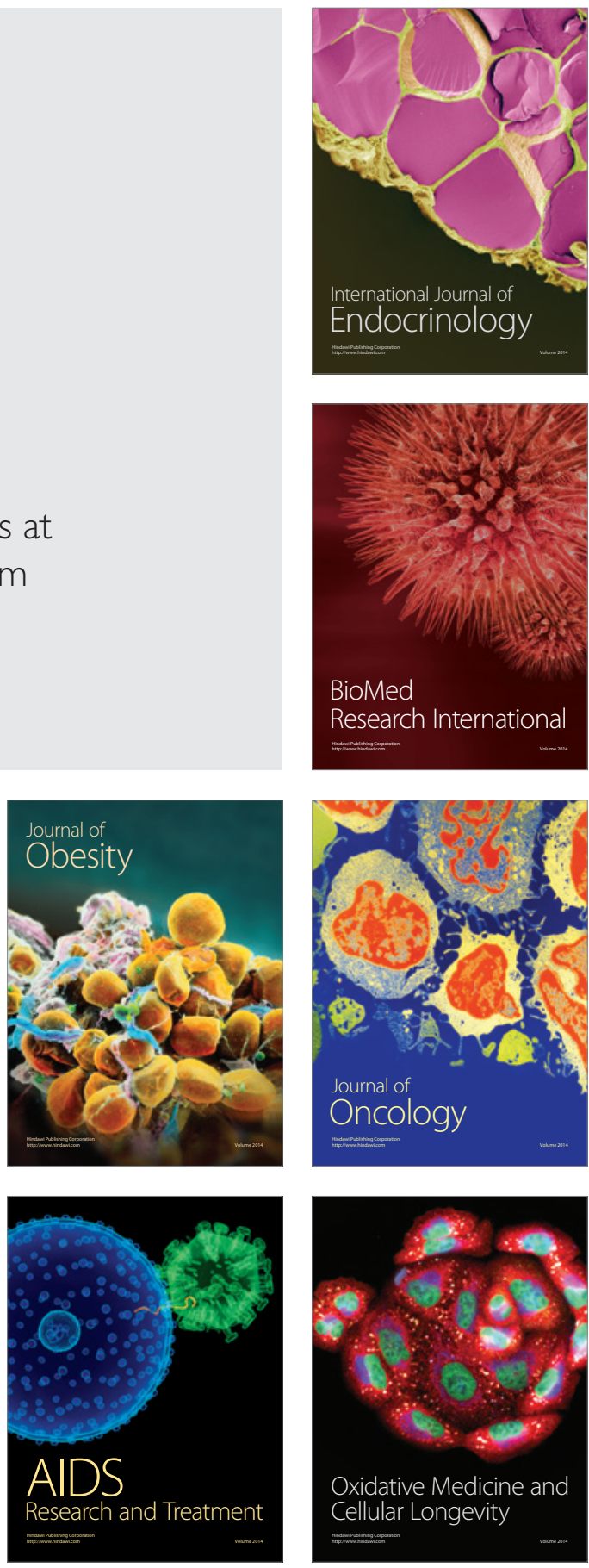